Vulnerability without capabilities?

Small state strategy and the international counter-piracy agenda

Smed, Ulrik Trolle; Wivel, Anders

Published in:

European Security

DOI:

10.1080/09662839.2016.1265941

Publication date:

2017

Document version

Peer reviewed version

Citation for published version (APA):

Smed, U. T., \& Wivel, A. (2017). Vulnerability without capabilities? Small state strategy and the international counter-piracy agenda. European Security, 26(1), 79-98. https://doi.org/10.1080/09662839.2016.1265941 


\title{
Vulnerability without capabilities? Small state strategy and the international counterpiracy agenda
}

\author{
Ulrik Trolle Smed and Anders Wivel
}

This is an Accepted Manuscript of an article published in European Security 26(1): 79-98.

Available online: http://www.tandfonline.com/ http://dx.doi.org/10.1080/09662839.2016.1265941

\begin{abstract}
Today, small European states regularly need to go out of area and out of tried and tested institutional settings to defend their security interests. How do small European states meet this challenge most effectively? This analysis suggests that small states can influence multilateral decisions on international security by combining norm entrepreneurship with lobbying and taking on the role as an 'honest broker'. However, economic capacity, an effective state administration and interests compatible with the agendas of the great powers are key to success. Based on a comprehensive empirical material including 19 elite interviews as well as official documents and other written material, we process trace how one small European state, Denmark, influenced the development of international counterpiracy cooperation and the development of an international counterpiracy strategy for the Gulf of Aden and off the Horn of Africa and discuss which lessons the Danish case may hold for other small states.
\end{abstract}

Key words: norm entrepreneurship, small state strategy, counterpiracy, influence seeking, maritime security, Denmark

\section{Introduction}

In May 2013, American diplomat Donna Leigh Hopkins, Chairman of the Contact Group on Piracy off the Coast of Somalia, made an important announcement at a Contact Group meeting in New York. She confirmed that it was now one year since pirates had successfully hijacked a merchant vessel off the coast of Somalia. Moreover, while 2011 saw 237 ships attacked by Somali pirates in the Gulf of 
Aden and off the Somali coast, this was down to 75 in 2012. Together with Danish Ambassador Thomas Winkler, Chairman of the Contact Group's legal working group, Hopkins unpacked what she saw as the key determinants of the successful strategy against Somali piracy, which included international military cooperation, industry guidelines for ship-owners, and prosecution and imprisonment of pirates (The Guardian, 2013).

This was a remarkable development. The early twenty-first century saw a dramatic rise in piracy off the Horn of Africa following the Somali civil war, the 2004 tsunami, and problems of illegal fishing and waste dumping in the area (Westberg, 2015; Bueger, 2015a). From 2005 this development became the subject of increasing international concern with the International Maritime Organization and others warning about the consequences of Somali piracy for commercial and security interests as well as the development of Somali society. This concern only increased in 2007 after the attack on three World Food Programme ships, and the UN Security Council subsequently agreed on resolution 1772 expressing concern about the consequences of piracy and calling upon all UN member states with military presence near Somalia to protect the seaways (UNSC, 2007). In October 2008, in Resolution 1838, the UN Security Council decided to request international forces to be deployed under Chapter VII of the UN Charter to fend off the pirate attacks from Somali vessels (UNSC, 2008a). A range of actors answered the call and contributed alone or in fluid multinational constellations under the mandate of the UN in the Gulf of Aden, Red Sea, Indian Ocean and Horn of Africa, e.g. in operations conducted by the EU, NATO or the US-led Combined Maritime Forces. In January 2009, following UN Resolution 1851, the Contact Group on Piracy off the Coast of Somalia was established as a voluntary, ad hoc international forum bringing together nearly 80 countries, international organizations such as the Arab League, the European Union, the International Maritime Organization and the North Atlantic Treaty Organization as well as a number of UN agencies and private sector representatives. After its establishment, the Contact Group became the primary forum for developing and implementing strategies to counter terrorism off the Somali coast and in the Gulf of Aden.

Denmark, a small European country with strong maritime interests, played a particularly active role in this development. Denmark succeeded in influencing the scope of the missions as it was revised from counterterrorism and counterdrug operations to counterpiracy, and Denmark also convinced its partners to move from defensive to offensive operations by gradually applying new modes of operation. Denmark took up key positions as organizational structures were agreed upon and benchmarks were created for future action. What later developed into Contact Group 
operations began as informal cooperation between Denmark, the United States, the United Kingdom and others, and grew into several multinational forums and maritime task forces, involving up to 60 different countries. In the end, Denmark had participated in almost all the available counterpiracy forums and task forces, contributing minds and ships, and had been a forerunner in doing so. The Danish opportunities for influence followed from great power interest in reducing piracy combined with a collective action problem for handling the issue in the face of greater challenges and the lack of clear institutional structures for creating and communicating policy responses. Denmark systematically sought influence on policy content as well as implementation as opportunities emerged, but Danish influence was highly contingent on the willingness of Danish policymakers to adapt their own agendas and arguments to make them fit with those of the great powers, most importantly the United States, and holding on only to a few political bastions of vital interest. In turn, Danish willingness to pragmatically frame its own arguments within the dominant discourses of the most powerful actors combined with its willingness and ability to back up action with financial and diplomatic resources created a political space for delegation of certain tasks to Denmark by the major powers. Denmark was not alone in identifying piracy as a major international problem and wanting to organize international cooperation to counter it (see e.g. Bueger, 2015b; 2016). Some type of counterpiracy cooperation is likely to have occurred even without Denmark's effort, but for Danish policymakers it was not only that it occurred but how it occurred and at which speed, which was of vital importance and in order to achieve these aims, they were willing to compromise on other issues.

The active pursuit of small states to maximize their security and influence is a relatively neglected subject in the study of international relations as small states are typically analysed either as at the receiving end of power politics or as providing an idealist anti-thesis to great power politics (Browning, 2006; Neumann \& Gstöhl, 2006). An evolving research programme on the foreign and security policies of small states have increasingly emphasized the strategic opportunities of small states. But so far this literature has mainly focused on how small states may exploit their strategic action space in highly institutionalized international environments such as the European Union (Bailes \& Thorhallsson, 2013; Björkdahl, 2008; Grøn \& Wivel, 2011; Jakobsen, 2009; Panke, 2011). We explore if the assumptions of this literature are applicable to an international security environment characterized by complex security challenges and weak international institutions, and to which extent the findings of the literature are relevant to small state strategies in such an environment. 


\section{Understanding small state strategy}

The contribution of small states to international security has traditionally been seen as marginal at best and counterproductive at worst. The scholarly literature typically identifies dependence as a shared characteristic of small states. Left with a smaller margin of time and error than great powers in times of security crises, because of their lack of hard military power (Jervis, 1978), they are unable to rely on their own resources for national security (Rothstein, 1968). Small states are also likely to free-ride and let the larger allies 'bear a disproportionate share of the burden', knowing that their military contribution is likely to be insignificant to the success or failure of the alliance (Olson \& Zeckhauser, 1966).

Emphasizing the risks of military attack and economic vulnerability, small states are expected to aim defensively at survival (Aron, 1966, p. 83) by pursuing hiding strategies, i.e. variations over the theme of neutrality, or shelter strategies, i.e. seeking the military and/or economic protection of one of the great powers (Bailes, Thayer and Thorhallsson 2016; Fox, 1959; Handel, 1981; Vital, 1967). Smallness is most often equated with the lack of power, and power is typically equated with capabilities (Browning, 2006). Capabilities refer to material resources, and thus the four most commonly used criteria for defining small states are population, territory, GDP and military capacity (Thorhallsson, 2006), all of which small states typically lack in one way or another (Keohane, 1969; Rothstein, 1968). Lacking these capabilities makes small states vulnerable to external factors, such as great power military and diplomatic influence and global trends in economy, climate change, etc. (Väyrynen, 1971). Echoing Clausewitz, Hans Morgenthau sums up the traditional small state definition: 'a Great Power is a state which is able to have its will against a small state $[\ldots]$ which in turn is not able to have its will against a Great Power' (Morgenthau, 1972: 129130).

Recently, this view of small states and their limited action space has been challenged. Drawing primarily, but not exclusively, on the experience of small West European states over the past decades, a number of authors explore how small states, typically within the highly institutionalized decision-making structures of the European Union, have pursued various strategies in order to maximize their influence over international affairs ( see e.g. Bailes \& Thorhallsson, 2013; Björkdahl, 2008; Grøn \& Wivel, 2011; Jakobsen, 2009; Panke, 2011). These authors point out how the vulnerability of small states may lead to pragmatic and cooperative responses to international crises. The small state focuses on efficient problem-solving and policy experimentation in order to meet challenges, and they often get away with behavior that would be impossible for a great power 
(Archer, Bailes \& Wivel, 2014; Cooper \& Shaw, 2009). Still, implicitly or explicitly, this literature accepts as its point of departure that a small state can only rarely change its external environment by force but must rely on diplomatic means of influence and persuasion (Bailes, Rickli \& Thorhallsson, 2014).

What are these diplomatic means of influence and persuasion? ${ }^{1}$ First the small state may take on the role of 'an honest broker', a mediator facilitating the negotiation of agreements and international treaties. By chairing negotiations small states may gain access to information otherwise not at their disposal, build relations with potential partners and affect outcomes by using the agendasetting powers bestowed at them by their function. Second, small states may take on the role of a lobbyist by utilizing their knowledge in a specific issue area to influence outcomes. In most cases, timing is decisive if expert knowledge is to be translated into influence. Therefore, keeping the agendas of powerful actors and relevant institutions under surveillance is key to success. Finally, a small state may take on the role of a norm entrepreneur to convince others of its ideas, and thereby create an ideational basis for changing the security environment and/or specific policies. Being a norm entrepreneur involves identifying the 'right' or 'desirable' behavior. For a small state this typically involves tapping into the discourses already dominating the political agenda. By presenting its own political initiatives as relevant contributions to meeting the challenges ahead as they have been defined by leading actors (i.e. the great powers), small states may influence 'niches' of particular relevance to their national interest. This is done most effectively if arguments are underpinned by action, i.e. by acting as a benchmark. As argued by Björkdahl, '[i]f the advocate also acts as a forerunner and complies with the norms it propagates, i.e. "practicing what you preach", the advocacy becomes more convincing' (Björkdahl, 2008: 137). While these three roles do not necessarily represent an exhaustive typology of the strategic opportunities available to small states, their noncoercive nature is typical of small states, because they can only rarely change their external environment by force but must rely on diplomatic means of influence and persuasion (Keohane, 1969). Thus, small states tend to seek influence on international affairs, understood as seeking to affect or change events or policies in their external environment, by use of political strategies, i.e. the deployment of diplomatic tools for achieving political objectives (Thompson, 2009: 17).

\footnotetext{
For a discussion of these diplomatic means of influence and persuasion in the context of the EU, see Grøn and Wivel, 2011, pp. 429-435. In contrast to e.g. Risse (2000) and Brommesson and Fernros (2013), we do not view influence and persuasion as based on two competing logics, but follow the classical approach of Keohane (1969) viewing non-coercive strategies such as persuasion as a way for small states to maximize influence despite their power deficit.
} 
Typically, the three roles are treated as analytically and theoretically distinct. For instance, Grøn and Wivel explore their importance in the European Union as three distinct strategies for maximizing small state influence, and argue that their relative applicability varies with the institutional set-up and the stage of the negotiation process (Grøn and Wivel 2011). In terms of theory, Björkdahl argues that constructivist approaches are better able to capture norm entrepreneurship dynamics than realist approaches (Björkdahl, 2007). However, our purpose is not to test when small states may gain influence by acting as a norm-entrepreneur as compared to acting as a mediator or a lobbyist, nor is it to single out whether 'realism' or 'constructivism' explains Danish counterpiracy strategy best. Instead, we aim to understand how a small European state like Denmark succeeded in influencing the international agenda on the issue. Instead of choosing between realism and constructivism, we acknowledge that small states seek to maximize their influence in the context of great power interests, but that these interests most often leave a room for small power agency that goes beyond delegation from great powers. Rather than viewing mediation, lobbying and norm entrepreneurship as three distinct strategies we seek to show how they interact. They are all part of the same toolbox, which is available to relatively secure and economic sound small states, who aim for influence beyond their immediate survival. Lobbying and mediation aim to achieve concrete results related to a particular policy issue. Meanwhile, norm entrepreneurship aims to influence, which policy issues will be important in the future, how they will be perceived, and what will be legitimate means and ways for international problem solving. This means that lobbying and mediation tools are typically embedded in more general strategies of norm entrepreneurship. They are tools, which can be used to modify and change norms within particular policy areas by supporting benchmarking and forerunner reputation efforts to actively increase influence.

In order to trace how Denmark influenced the international counterpiracy agenda, we identify the most significant actors within the counterpiracy policy area as well as the fit between the Danish norms and those of the agenda-setter(s). In practice, we identified the dominant discourses via scientific journals, newspaper articles, as well as documents and newsletters from international organizations, e.g. the United Nations Office on Drugs and Crime (UNODC), and naval task force operation centres. In order to assess how and to which extent Denmark successfully tapped into those discourses, we conducted 19 elite interviews with Danish, European and US participants in international negotiations on counterpiracy and in military counterpiracy actions off the coast of Somalia. Finally, we triangulated our findings from these interviews with written material such as academic analyses and news sources and official documents from the Danish Parliament (Folketinget) 
and Danish government institutions, e.g. the Ministry of Foreign Affairs and Navy Operational Command.

\section{International counterpiracy norms and Danish policy preferences}

From 2008, Danish vessels were involved in counterpiracy operations in the Gulf of Aden. Danish policy-makers soon identified three challenges.

First, states inside and outside the region viewed piracy as a national problem. Flag states were expected to take care of their own vessels, e.g. by deploying naval forces to the Horn of Africa, and to handle their own pirate suspects. Deploying enough naval vessels to protect the Danishcontrolled merchant fleet was not a realistic option for a small state like Denmark with approximately 100 Danish-controlled merchant vessels navigating off the Horn of Africa at any given time. Moreover, Danish shipping business had always relied on the freedom of the seas as a global public good during the hegemonies of first the British Empire and later the United States. Consequently, Denmark perceived piracy as an international problem, which required international solutions, when local or regional guardians failed to provide this perceived international public good.

Second, some states, such as the United States (Smed, 2015a, p. 55), viewed piracy as an irritant rather than a strategic threat. These states had been present in the region for decades and viewed piracy as one problem among many, and for them an increase in piracy did not amount to an international crisis, which required international attention and action. In contrast, Denmark, a small country controlling approximately ten percent of global shipping, was in a hurry to find a solution due to the potential repercussions for the Danish national economy.

Third, when states did catch pirates, they first sent them to face trial in their own national courts, mostly in Western Europe. Thus, the burden of undertaking and financing prosecution was borne by the individual state rather than the international community. At the same time, this state would face the almost impossible task of deporting convicted pirates back to Somalia to serve their sentence, since European legislation prohibited forced repatriation to politically unstable countries. When the international community realized this, a range of countries - including France, Germany, and Russia (Smed, 2015b, pp. 6-7) - requested the establishment of an international piracy court, possibly located in the region but designed in line with similar courts and with an international, rotating, staff. To Denmark, these were two equally unattractive solutions: Western court systems created bottlenecks and succumbed the prosecuting state to economic and political costs, but the creation of an international piracy court demanded cumbersome international negotiations with little 
guarantee of the creation of an effective court in the end. Thus, few pirates were convicted in Europe and even fewer would be picked up in the Gulf of Aden over time as it became clear that no effective prosecution framework was available.

In response to these challenges, Denmark identified three political priorities to guide its counterpiracy policy in the region. First, the international community, including the great powers who had longtime interests in the region, should view piracy as an international problem requiring collective international solutions. Second, the recent increase in piracy in the Gulf of Arden constituted an international crisis that needed immediate action, and therefore required states to focus their naval forces in the area, or to dispatch available vessels, on counterpiracy operations. Finally, cost-effectiveness was key for a small economy with large shipping interests. This led to an effort to create sustainable regional solutions rather than leaving the problems to individual states or aiming for an all-encompassing international solution.

These three policy priorities translated into a Danish norm entrepreneur strategy in two related domains: 1) to revise the norms for the use of multinational naval forces in the region; 2) to establish a norm for building on existing local justice systems in the region to prosecute suspected pirates. Below, we trace each of these processes of Danish norm entrepreneurship.

\section{To entrepreneur the use of multinational naval forces}

Denmark spent considerable resources on seeking to establish a new modus vivendi for multinational naval forces in the Horn of Africa region. This involved tapping into dominant discourses about the region and their related naval operational frameworks. Over time, the Danish behavior constructed a benchmark for other nations to measure against. The aim was to establish piracy as an international problem, which required an international solution sooner rather than later.

Tapping into dominant discourses of the World Food Programme (WFP) and the Combined Maritime Forces $(C M F)$

Denmark first sought to counter piracy by tapping into the ongoing Somali Civil War, following UNSC Resolution 1772. WFP vessels carried humanitarian aid from Kenya to Somalia to alleviate starvation, but increasingly they experienced attacks from Somali pirates. About 80 percent of the assistance was seaborne, and by mid-2007 half of the WFP maritime contractors employed refused to work without naval escorts. The UNSC regarded this as the beginning of a humanitarian and political crisis for Somalia (UNSG, 2007, p. 3), and called for multinational escorts (UNSC, 2007). 
Among other things, Denmark responded by deploying Thetis, an old ice-reinforced Arctic inspection ship, carrying 80 troops, special forces and speedboats. Denmark was only able to deploy a few vessels to international operations, and thus, the decision to deploy the ship reflected the expectation of the Danish Parliament that Denmark was about to engage actively in combatting piracy and that this was an issue of national interest (Danish Parliament, 2008). Thetis hardly came into contact with anyone but escort ships and ragged Somali protection teams and returned home after three months without encountering any attacks (Danish Defence Command, 2008a), but nonetheless the deployment helped establish Denmark's forerunner reputation on the international counterpiracy agenda, with the UNSC commending the Danish (and French) contributions (UNSC, 2008b).

Denmark also played into the maritime security operations of the CMF led by the U.S. Fifth Fleet in Bahrain. The CMF was rotating between a mix of counterdrug, counterterrorism and counterpiracy operations. Piracy had little traction in the US debate except for a growing speculation about a potential tactical nexus between pirates and terrorists (Chalk, 2008, p. 31): Combatting Somali piracy could potentially become 'the war on terrorists at sea' (Luft and Korin, 2004, p. 70), and oil tankers a new 9/11 weapon for al-Qaeda (Murphy, 2007, p. 60). In 2007, a U.S. Fifth Fleet warship had chased and destroyed three empty pirate skiffs towed after the hijacked Danish merchant vessel Danica White. The previous day, the US warship had been firing its five-inch guns at suspected al Qaeda members on the Somali coastline (CNN, 2007). However, the United States was at war with insurgents in Iraq and Afghanistan while waging a global war on terror with more than 270,000 troops deployed to these ends (Amy Belasco, 2009, p. 6). In this context, piracy was an annoyance, not a strategic issue, for the superpower. Denmark had recently pulled out combat troops from Iraq only to deploy them to Afghanistan. However, as the hijacking of Danica White made the front pages of Danish newspapers for three straight months, Denmark found its own war to fight at the Horn of Africa (HOA).

The brand new frigate-sized Danish vessel Absalon left to take command of Combined Task Force 150 (CTF150) in August 2008 as Denmark sought to convey the idea that counterpiracy was an international problem in dire need of attention. ${ }^{2}$ The Danish government gave its fleet a robust national mandate for counterpiracy operations, which they perceived had strong potential to influence

2 The CMF was "mainly focused on the smuggling of heroine, weapons and fighters between the Arabian Peninsular, Africa and Pakistan, in smaller vessels, as it had been the business as usual up to then ... Piracy was a fairly new but rapidly increasing threat, and fight against piracy was the strategic focal point for Denmark and the most important task for us. But it took us months to make the U.S. headquarters altering course just a little away from business as usual and give more priority to counterpiracy." (Interview with Per Bigum Christensen, 2014). 
the agenda. ${ }^{3}$ However, CMF coalition partners viewed piracy as a national problem. Some nations regularly prevented piracy attacks, but mostly for those vessels with their own flag, while others had taken a 'hands off' approach (Danish Defence Command, 2008b; Guilfoyle, 2010, pp. 141-142, 152). With piracy attacks spiking, the Danish Commander was allowed to direct task force units to focus solely on piracy (House Armed Services Committee, 2009, p. 3). Subsequently, Absalon detained suspected pirates several times (Danish Defence Command, 2008c). However, the approach was draining resources from other tasks, and differences among coalition partners on whether piracy was a multinational or national responsibility became more visible. By November, the different national mandates resulted in a French ultimatum to the CMF leadership - if counterpiracy remained as the focus of attention, France would ultimately reduce or withdraw from the coalition. ${ }^{4}$ The US command was forced to choose between coalition coherency and counterpiracy, and the Danish position was becoming increasingly controversial. ${ }^{5}$ However, international attention to counterpiracy was growing. Two competitors for multinational naval forces entered the region - NATO Operation Allied Provider (OAPROV) and EU Operation Atalanta (OATA) (Riddervold, 2014; Struwe, 2009). A month later, Bahrain established its own naval counterpiracy unit, Task Force 151 (CMF, 2009).

In this context, the Danish Government allowed a wide national mandate for action and sought to provide useful naval vessels for combating piracy in order to influence regional commanders and push the existing international framework in the direction of Danish interests. As stated in one policy paper, Denmark was working for a 'general increase in the operative use of standing naval forces, including an extended use of these in the fight against piracy' (Danish Ministry of Foreign Affairs, 2009, p. 14).

3 "National preparation on strategic level is everything. What do you want to achieve by sending a national contribution to a multinational operation? Denmark came prepared with robust rules of engagement, and that influences the agenda. If you don't have that, you can have the backseat." (Interview with Per Bigum Christensen, 2014).

4 "We had turned task force 150 from focusing on normal illegal activities at sea to a counterpiracy focus. The problem was that some nations did not want the task force to have that focus ... When the Americans bought into our new direction of the task force, to counterpiracy, the French indicated: 'If you do that, we won't be sending any more ships'. And they were the ones who traditionally provided the most ships to Task Force 150. They knew that piracy was a big problem, but wanted nations to take care of it through national tasking." (Interview with Per Bigum Christensen, 2014).

5 "Vice Admiral Gortney was worried that this would split the coalition, and it was his political assignment to maintain a strong organization with regional influence. Denmark had become a liability to Vice Admiral Gortney, because we focused so narrowly on counterpiracy. But the different national mandates and rules of engagement forced this kind of situation." (Interview with Per Bigum Christensen, 2014). 


\section{Benchmarking on counterpiracy operations}

The 2011 Danish counterpiracy strategy - written at a time when Danish vessels had been deployed for around two years already - aimed to strengthen Danish forerunner reputation even further by explicating the ambition to deploy a frigate-sized vessel for six months and a maritime patrol aircraft for shorter periods each year (Danish Ministry of Foreign Affairs, 2011, p. 18). Thereby Denmark hoped to set a benchmark for other (small) states, including the Netherlands. ${ }^{6}$ Another Danish benchmarking move was to lead by example and actively take prisoners in order to heighten task force effectiveness. ${ }^{7}$ In one statistics from 2012, the efforts of Danish vessels to catch pirates at the HOA made up about 43 percent of all suspects delivered to Kenyan authorities waiting for prosecution (UNODC, 2012, p. 2). By June 2011, Danish vessels had been deployed to HOA counterpiracy operations for 27 months, rising to 50 months by 2014, equaling four years of deployment over a six-year period (Danish Defence, 2015). Instead of rotating the deployed vessels, Denmark was rotating the crews. This unconventional approach enabled Danish vessels to optimize their time and impact at sea (Danish Defence Command, 2008d).

Furthermore, Danish officers were becoming de facto active military leaders of the counterpiracy agenda. From 2008-2014, Denmark had command of CTF-150 once, CTF-151 thrice, Standing NATO Maritime Group (SNMG) 1 twice, and NATO Task Force 508 (TF508) once (Danish Defence, 2015). This amounted to 22 months, or almost two years, of continuous task force leadership (Danish Defence, 2015). Reflecting on these achievements in May 2014, Danish Chief of Naval Staff Frank Trojahn explained his view of the opportunities presented by the Danish reputation: 'People want us there. We have just been asked, if we can prolong Esbern Snare with another four months in the CMF. NATO wants us there. They want us to lead operations. They are only asking this, because they know they are getting a sound product' (Interview with Frank Trojahn, 2015) .

\section{Establishing a norm for the use of existing courts in the region}

"You definitely set an example for others, and you became a benchmark ... For the navies of smaller states, this is the mission of the moment, and you go two-hundred percent for it" (Interview with Michiel Hijmans, 2014)

7 'I think it made a difference that we went down there and did something, tried seriously to make a difference ... You could have chosen a more cautious approach and perhaps then someone else, if there were others, would have been in the limelight ... But that was not the approach we had. We seriously wanted to make a difference - and we succeeded to a large extent." (Interview with Frank Trojahn, 2015). 
Denmark also spent considerable resources promoting the norm of regional (as opposed to national or global) institutions and procedures for the prosecution and incarceration of Somali pirates. This strategy of norm entrepreneurship included tapping into international discourses on fragile states and capacity building in the region and a series of mediation and lobby efforts in international forums such as the Contact Group on Piracy off the Coast of Somalia (CGPCS) and Working Group 2 (WG2). The initial aim was to create a cost and time effective solution to deal with the surge in piracy, but Danish policy-makers focused increasingly on the long-term and saw their preferred institutional solutions as an important contribution to a sustainable counterpiracy framework.

\section{Tapping into discourses on fragile states with regional capacity building}

Denmark sought to reduce the piracy problem by tapping into dominant development discourses on stabilizing fragile states such as Somalia, which was viewed as 'the archetypical failed state' with several attempts to setup stable peace agreements, institutions and governments (ICG, 2008, p. i). Without stable governments, states were expected to fall apart and turn into breeding and training grounds for transnational terrorism, crime and other security threats (Kilcullen, 2006; Krasner \& Pascual, 2005; Rotberg, 2003), and in the eyes of the UNSC, Somalia was in dire need of support for 'long-term stabilization and post-conflict restoration' (UNSC, 2007). From 2008 Denmark answered this call for contributions by allocating funds for development and capacity building on counterpiracy in East Africa aiding judicial capacity building of the Somali counterpiracy police units, renovating prisons in Puntland, and setting up a post-trial transfer program in the Seychelles (DANIDA, 2010, p. 75). Denmark was co-founder of the regional prison projects, together with a group of core states providing about half of the $\$ 53 \mathrm{~m}$ UNODC Counter Piracy Programme funding, ${ }^{8}$ with Denmark donating \$5.1m from 2009 to 2014 (UNODC, 2015, p. 26).

Denmark increasingly used its economic leverage for negotiating a shift in focus among the donor states towards building local maritime security capacities. In 2009, Denmark created the new Global Framework Fund (GFF), subsequently renamed the Peace and Stabilization Fund (PSF), holding $150 \mathrm{~m}$ DKK for stabilization, rebuilding and capacity building projects in conflict areas with a comprehensive approach all over the world - including Eastern Europe, Central Asia, and East Africa (Danish Ministry of Defence, 2009, p. 20). In the words of Danish MFA Lene Espersen, there

"Norway basically funded the prisons in Puntland and Somaliland - jointly with Denmark and Netherlands and UK - and subsequently employed mentors ... to the prisons." (Interview with Alan Cole, 2015). 
could be 'no security without development and no development without security' (Danish Minister of Foreign Affairs (Lene Espersen), 2010, p. 1). In 2010, the GFF consequently built coast guard capacities in Yemen and Djibouti (DANIDA, 2010, p. 75), and in 2011-2012 its successor, the Peace and Stabilization Fund (PSF), dedicated $215 \mathrm{~m}$ DKK to the HOA with $103 \mathrm{~m}$ DKK aimed at preventing and combating piracy off the coast of Somalia, including support for regional judicial and maritime capacity building (Danish Parliament, 2011, p. 2). However, a substantial part of the money was left unused when the Kenya Coastal Radar project was later cancelled (Coffey, 2014, p. 16). The Danish contributions to the DCCTF also prioritized regional coast guard capacity building with $\$ 1,5 \mathrm{~m}$ (IMO Maritime Safety Division, 2014, p. 4). The counterpiracy strategy from 2015 continued this approach, though at a significantly lower rate, with $7 \mathrm{~m}$ DKK to counterpiracy military capacity building in East Africa (Danish Ministry of Foreign Affairs, 2015, p. 7). Meanwhile, a larger part of Danish development aid was allocated for countering threats abroad. Approximately $60 \mathrm{~m}$ DKK was allocated for local food production and refinement with the purpose of increasing wages and living standard in poor areas viewed as potential recruiting grounds for radical organizations or 'destructive economies based on piracy, arms dealing and smuggling' (Danish Minister of Foreign Affairs (Holger K. Nielsen), 2014, p. 6). As noted by Danish and international actors, the support for local capacity had become a fundamental part of Danish influence seeking. ${ }^{9}$

\section{Being an honest broker in CGPCS and WG2}

Economic influence seeking was accompanied by diplomatic influence seeking in international forums. The first move was to present Denmark as an honest broker. In December 2008, Denmark was requested by the U.S. to volunteer as chair for WG2 in the Contact Group on Piracy off the Coast of Somalia (CGPCS). The Danish government had been very vocal about the need for an international solution to the so-called 'impunity problem' (Jyllands-Posten, 2008; Politiken, 2008; Weekendavisen, 2008a, 2008b). Only a few of the detained suspected pirates were prosecuted, since evidence seemed insufficient for conducting trials, and states were concerned if they could extradite ex-convicts back to Somalia (Danish Defence Command, 2008b; Guilfoyle, 2010, pp. 141-142, 152).

\footnotetext{
"Not even two months ago, I had a Somali delegation visiting Admiral Danish Fleet headquarters as part of a comprehensive program, where they could hear about our experiences with building surveillance systems for Danish territorial waters. This is something they should be able to do themselves to prevent illegal fishing and control their territorial waters." (Interview with Frank Trojahn, 2015). "Denmark is a major supporter of our work to rebuild the Somali maritime force capability and to provide further support to the coast guard in the Seychelles and the maritime police ... [through the Danish Nairobi delegation].” (Interview with Alan Cole, 2015).
} 
For a maritime small state without the resources to 'go-it-alone', this was an excellent opportunity for seeking influence on the counterpiracy agenda. While major powers tend to distrust one another's intentions for either security or competitive reasons, this was different for a small state. As noted by Ambassador Thomas Winkler, the former Danish WG2 Chairman, 'very few countries suspect Denmark of having a secret agenda. We are not big enough' (Interview with Thomas Winkler, 2014).

\section{Linking to vetted outside expertise}

Positioned as an honest broker in WG2, Denmark first sought to mediate in order to arrive at a consensus definition of piracy among member states by linking to outside academic expertise in 2009. This would benefit Danish interests as a consensus definition could serves as a point of departure for collective action. However, Malaysia and Indonesia feared that authorizing the use of force in Somali territorial waters could result similar discussions for the Indonesian archipelago, where piracy was also problematic (CGPCS, 2009a, p. 1). From a Danish perspective, this represented a potential delay. Circumventing the problem, the Danish Chair invited Dr. Douglas Guilfoyle, a legal scholar from University College London, to clarify the basis for prosecuting suspected pirates (CGPCS, 2009b, p.

2). This was unusual at the time, but turned the meetings into 'something much less formal' (Interview with Douglas Guilfoyle, 2014). Some states were skeptic at first but later welcomed the approach as useful. Others, like the U.S., seemed surprised how smoothly traditional high politics sovereignty issues were swept aside. ${ }^{10}$ By including outside expertise, Denmark sought to make international counterpiracy efforts more about practical solutions than theoretical considerations or ideological positions. This tapped into the international discourse on fragile states as a hand-on security problem in search of practical solutions and benefitted Danish interests by facilitating that these international solutions would be collective. Instead of trying to influence the document directly, Denmark vetted and included an academic expert and made great efforts that Guilfoyle's points were well-received. ${ }^{11}$. Other academics and 'outsiders', including several Danish stakeholders, were later invited to present at WG2 meetings. These included a Danish naval Commander, shipowner Per Gullestrup (CGPCS,

10 In fact, the untraditional approach was so successful that "... the U.S. delegation said to me, after the third meeting where I presented my report ... 'Douglas, the value that you brought to this process is - and I don't mean this in any way to diminish your achievement - that the document you produced was nothing we could not have produced ourselves, but you have saved us about a year and a half' ..." (Interview with Douglas Guilfoyle, 2014).

11 "I learned later that Thomas had asked several delegations, who thought it was a good document, to speak in favor of it, when it came up for discussion, so that the first two or three voices would be positive." (Interview with Dr. Douglas Guilfoyle, June 19, 2014). 
2009b, p. 2), MFA Lene Espersen (CGPCS, 2010a, p. 4), and Associate Professor Birgit Feldtmann (Interview with Birgit Feldtmann, 2014).

\section{Linking to the UNODC Regional Office (UNODC-Nairobi) for expertise, partners and capacity}

Denmark also utilized the expertise of the UNODC office in Kenya. From 2008, the Danish Chair and the Office increasingly cooperated on international piracy prosecution efforts through meetings in Nairobi, Vienna and Copenhagen (CGPCS, 2009a, p. 1). In 2009, an estimated 90 percent of suspected pirates were released without trial due to lack of regional prosecution mechanisms (UNSC, 2011a, p. 13). A few countries were trying to prosecute suspects domestically but many cases were rejected because of the lack of evidence (CGPCS, 2009b, p. 2). To make this point the Danish Chairman invited UNODC Programme Coordinator Alan Cole to present regular overviews of the legal regulations of member states prosecuting suspected pirates. ${ }^{12}$ While prosecution rates stagnated, UNODC-Nairobi introduced Denmark to partners in the Seychelles. ${ }^{13}$ This tiny nation of only 90,000 people was extremely dependent on cruise ship tourism and fishery, and consequently threatened by piracy. The Seychelles had a competent judicial system, but they lacked prison facilities and offered multinational naval forces to prosecute the detained suspects (Interview with Thomas Winkler, 2014). The Chairman invited Somali delegations from Mogadishu, Hargeisa and Garoowe to the Seychelles to negotiate a transfer agreement (Interview with Thomas Winkler, 2014). Denmark then turned to UNODC-Nairobi for help in order to increase regional prison capacity. UNODC-Nairobi proposed 'do the doing' and build prisons, if Denmark would do 'the thinking'. ${ }^{14}$ As noted by Winkler: 'it wasn't Denmark that built those prisons, right? It was the UN' (Interview with Thomas Winkler, 2014).

12 "He would chair the meeting and we would do the presentations. He would then deal with the questions from the floor, and we would generally answer them." (Interview with Alan Cole, 2015).

13 "The UNODC had counseled the Seychelles for many years on counterpiracy law, which meant we had a pretty modern legislation in the region." (Interview with Thomas Winkler, 2014).

14 "The prisons were a mainstream UNODC thing. Once the concept, which was developed by the UNODC, of transferring people back to Somalia ... was agreed, then he had little involvement in the construction of the prisons ... He [Chairman Winkler] would do the thinking and we would do the doing ... The Contact Group quickly came up with a load of work that needed to be done, and we [UNODC] jumped in and agreed to do it. So we developed a program specifically to do that work." (Interview with Alan Cole, 2015). 


\section{Building a special relationship and providing expert knowledge to UNODC-Nairobi}

Based on the existing working affiliation, Denmark sought a special relationship with UNODC, which enabled Denmark to survey and advice on UNODC-Nairobi agendas and documents; a primary source of information on piracy for CGPCS states. ${ }^{15}$ The relationship developed gradually as Denmark and the Office realized their shared interests. Denmark wanted a like-minded regional partner ${ }^{16}$ while UNODC-Nairobi sought easier access to government level conversations. ${ }^{17}$ Denmark met with the 'friends of the chair', which included representatives from core states and UNODCNairobi, for preliminary circulation and discussion of information before WG2 meetings in order to gauge support for Danish propositions and policy positions. UNODC-Nairobi wrote reports and standard transfer agreements for WG2 and its member states, and shared them with Denmark for judicial and political inputs prior to meetings (Interview with Alan Cole, 2015). This gave Denmark an exceptional opportunity for agenda-setting negotiations. ${ }^{18}$ Typical for a small state, these relationships were not checked and balanced by other actors, as would have been the case had Denmark been viewed as a major power. As noted by UNODC programme coordinator Alan Cole, a 'neutral' organization like the UN could not have built the same working relationship with one of the great powers as it would have been viewed by other states as siding with a particular foreign policy agenda. ${ }^{19}$

15 "I would think that $80 \%$ of the feedback on counterpiracy operations was done by the UNODC ... Most of the response to Somali piracy on the law enforcement side - from the transferring stage to the trial and the prison conditions - was the UNODC output." (Interview with Alan Cole, 2015).

16 "I had a phenomenal working relationship with the UNODC in Nairobi ... The piracy unit in that office had the exact same approach as we did" (Interview with Thomas Winkler, 2014).

17 "It wasn't that the Danish government raised the profile of the UNODC, it was more that by chairing working group 2 they made our lives a whole lot easier ... To be honest, it would have been difficult for me to engage in discussions with Somalia or the Seychelles without having to have brought in more senior people from headquarters ..." (Interview with Alan Cole, 2015).

18 "We drafted it, sent it in for comments, and he [the chairman] sent back twelve comments ... and we incorporated it, and that was that. Those agreements were shared with Working Group 2, and on the basis that the Danish government and the UNODC thought it was good, nobody else said a word ..." (Interview with Alan Cole, 2015).

19 "We had to be extremely careful, because the United Nations obviously is a neutral organization and we don't favor one member state over another. However, obviously in this circumstance, we had a particular close relationship with Denmark and Norway ... They're not states, which people tend to object in the UN complex ... Had we had that close relationship with the United States, for example, or maybe the United Kingdom, I think people would have raised questions ... It would be more likely that those states would have a sort of particular foreign policy agenda ... But Denmark and Norway are not states, which are particularly controversial in this region. They don't have a historical or colonial role." (Interview with Alan Cole, 2015). 
Denmark sought opportunities to use its growing forerunner reputation on legal counterpiracy issues as well. By quickly volunteering as chairman for WG2, Denmark was put in a league with the U.S. and the U.K. who chaired two other working groups (CGPCS, 2009c). Denmark was also quick to incorporate piracy in national policy papers on Somalia (Danish Ministry of Foreign Affairs, 2009, p. 14) and to produce a comprehensive counterpiracy strategy (Danish Ministry of Foreign Affairs, 2011, p. 18). Through 2009, WG2 produced considerable results and the Danish Chair received much credit for it from the CGPCS (CGPCS, 2009d, 2009e, 2009f) and the UN (UNSC, 2012a, p. 1, 2011b, pp. 9-10, 2011c, pp. 5, 14, 2010a, pp. 4, 8, 9). A noted by Winkler, building a strong reputation for effective negotiation and action in counterpiracy enabled Denmark to convey legitimacy to its selected partners thereby further strengthening the Danish position. ${ }^{20}$ This reputation was also used for avoiding the reopening of and effectively shutting down old discussions, even when confronted with stronger institutional actors such as UN and EU agencies on certain cases of human rights at sea and juvenile pirates (Interview with Alan Cole, 2015).

\section{Knowledge of domestic and encompassing preferences on the international piracy court}

Finally, from 2009 Denmark sought influence by utilizing knowledge of domestic and encompassing preferences. With diverging international opinions on how to prosecute suspected pirates most effectively, Denmark favored tying together regional judicial systems rather than establishing an international piracy court arguing that the majority of states supported this position (CGPCS, 2009g, p. 3). Furthermore, Denmark consulted with regional states, including Somalia, rejecting the idea of an international model (Smed, 2015b, pp. 6-7). The CGPCS subsequently encouraged states to support the Danish approach (CGPCS, 2010b, p. 3), but three months later the UNSC revived the debate (UNSC, 2010b, p. 3). Knowing that preferences in WG2 were in line with Denmark's position, the Danish Chair sought to stand its ground against continued suggestions for alternatives from the newly appointed UN Special Adviser (UNSA). In January 2011, the UNSA recommended an ambitious plan to establish an extraterritorial court (UNSC, 2011a, pp. §34, 38-40), which had been rebuffed earlier in WG2 (CGPCS, 2010c, p. 7). While the Council accepted the plan for an 
extraterritorial court and requested further information on implementation (UNSC, 2011d, p. 5), WG2 simply stopped having substantial discussions about anything but the national model. According to the UNSA's own report, regional actors were backing the national model (UNSC, 2011e, pp. §5255; §57-59). ${ }^{21}$ Also, by March 2011, about 80 percent of all prosecutions were being processed in regional courts, a number which rose by 26 percent to 1045 over the next three months (CGPCS, 2011a, p. 2, 2011b, p. 2). Still, the Council requested that the Somalis were asked again (UNSC, 2011f, pp. 4-5), ${ }^{22}$ and kept requesting the implementation of an international model until two years later, when the aspirations evaporated (UNSC, 2012b, p. 7, 2011g, p. 6), and the UNSC simply acknowledged that Somali piracy was at its lowest since 2006 and commended the regional states for their work on prosecutions in national courts (UNSC, 2013, p. 4).

\section{Conclusions and lessons learned}

The story of Danish counterpiracy norm entrepreneurship is a story of a small state successfully getting international influence on a salient policy issue, despite its lack of capabilities and vulnerability to external factors. But it is not a linear story of a small state rationally devising and implementing a counterpiracy strategy. Some actions preceded the 2011 Danish counterpiracy strategy, which in turn served both as a codification of what Denmark was already doing (or attempting to do) and as a platform for further action and influence. Moreover, Danish counterpiracy initiatives were highly context-dependent, and Danish policy-makers, diplomats and military officers were forced to work from a platform of vulnerability and necessity. Therefore, they would dismiss a range of counterpiracy efforts as unrealistic or inefficient, such as the idea of an international piracy court.

The tools for Danish influence were a combination of mediation, lobbying and normentrepreneurship, which stayed safely within the discursive boundaries of the international community, in particular the Western great powers. In particular, Danish policy initiatives were embedded in piracy discourses linked to terrorism and fragile states. Denmark maximized its influence on collective policy efforts, which could provide fast and pragmatic solutions to challenges, which threatened Danish maritime economic interests. Denmark positioned itself as a norm entrepreneur by establishing a forerunner reputation early on in the process, and practicing what it

21 UNSC, 'Report of the Secretary-General on the Modalities for the Establishment of Specialized Somali Anti-Piracy Courts' (June 15 2011)

22 The specific wording is "further consult with Somalia and regional States". 
preached by deploying staff and vessels and supplying economic means for the policies it promoted. By utilizing this reputation, Denmark also served as a benchmark for others and an effective mediator, in particular as a working group chair, while lobbying for specific solutions to the piracy problem. Danish policy on the issue was a success measured in terms of ends (speeding up of the processes), ways (practical hands-on solutions), and means (military, political, and economic). In conclusion, Denmark effectively utilized its lack of capabilities to position itself as a non-threatening, yet influential, actor with regards to the international counterpiracy agenda, while a robust Danish economy allowed Denmark to allocate the necessary means for military deployments, diplomatic maneuvering, and economic donations.

Based on this conclusion, the study holds three lessons for small states' aiming to maximize their influence on selective policy issues. First, Danish influence on the international counterpiracy agenda illustrates the utility of small state norm entrepreneurship outside the heavily institutionalized Euro-Atlantic area. The international debate on how to meet the challenges posed by piracy off the coast of Somalia were dominated by Euro-Atlantic actors (the United Kingdom, the United States) and an international organization (UNODC-Nairobi). This points to the 'overspill' of institutional practices from the heavily globalized and institutionalized Euro-Atlantic area to other parts of the international system. Second, Danish influence was the result of weak relative capabilities (compared to the great powers), which made Denmark appear unthreatening, and relative economic prosperity and administrative capacity, which allowed Denmark to allocate means towards influencing norms and contributing to concrete problem-solving. Thus, the Danish experience is mainly relevant for other rich small states with well-functioning bureaucracies and diplomatic services. Finally, Danish influence was as much a consequence of great power disinterest or even tacit delegation as it was a consequence of Denmark's own efforts. Denmark framed its own interests within the dominant discourses allowing it to build on an already strong relationship with the United Kingdom and the United States and a good reputation within the UN to influence the counterpiracy agenda. Strongly embedded in these relationships, Denmark was less vulnerable than small states outside the mainstream, but still Denmark sought and achieved influence within the boundaries set by the stronger actors. These three lessons illustrate the two sides of the coin for small states seeking influence on international agendas. Lack of capability can mean vulnerability, but it can also be translated into opportunity. However, these opportunities are primarily available to a select group of small states, primarily located in Europe, characterized by a solid economy, an effective state 
administration (including diplomacy and defence), and foreign policy interests compatible with the political agendas of the great powers. 


\section{References}

Archer, Clive, Alyson Bailes and Anders Wivel (eds), 2014. Small States and International Security: Europe and Beyond. London: Routledge.

Aron, R., 1966. Peace and war; a theory of international relations. Doubleday, Garden City, N.Y.

Bailes, Alyson J. K. and Baldur Thorhallsson, 2013. 'Instrumentalizing the European Union in Small State Strategies'. Journal of European Integration, 35 (2), 99-115.

Bailes, Alyson, Jean-Marc Rickli and Baldur Thorhallsson, 2014. 'Small states, survival and strategy' in Clive Archer, Alyson Bailes and Anders Wivel, Small States and International Security: Europe and Beyond. London: Routledge, 26-45.

Bailes, Alyson JK, Bradley A. Thayer, and Baldur Thorhallsson, 2016. 'Alliance theory and alliance "Shelter": the complexities of small state alliance behaviour'. Third World Thematics 1(1), 9-26.

Belasco, Amy, 2009. 'Troop Levels in the Afghan and Iraq Wars, FY2001-FY2012: Cost and Other Potential Issues'. Washington, D.C.: Congressional Research Service.

Björkdahl, Annika, 2007. 'Swedish norm entrepreneurship in the UN'. International Peacekeeping, 14 (4), 538-52.

Björkdahl, Annika, 2008. 'Norm Advocacy: a small state strategy to influence the EU'. Journal of European Public Policy, 15 (1), 135-54.

Brommesson, Douglas, and Henrik Friberg Fernros, 2013. 'The feasibility of an expanded regime on the use of force: the case of the responsibility to protect'. Journal of International Relations and Development 16(1), 138-166.

Browning, Christopher, 2006. 'Small, Smart and Salient? Rethinking Identity in the Small States Literature'. Cambridge Review of International Affairs, 19 (4), 669-84.

Bueger, Christian, 2015a. 'After Piracy: Towards an African Maritime Security Architecture', in Francois Vrey and Thomas Mandrup Towards Good Order at Sea: African Experiences. Stellenbosch: Sun Media, 35-50.

Bueger, Christian, 2015b. 'Learning from piracy: future challenges of maritime security governance'. Global Affairs, 1(1), 33-42.

Bueger, Christian, 2016. 'Doing Europe: agency and the European Union in the field of counterpiracy practice'. European security, 25(4), 407-422.

CGPCS, 2011a. 7th Meeting of Working Group 2 on Legal Issues, Copenhagen. 
CGPCS, 2011b. 8th Plenary Session of The Contact Group on Piracy Off the Coast of Somalia, New York.

CGPCS, 2010a. 5th Meeting of Working Group 2 on Legal Issues, Copenhagen.

CGPCS, 2010b. 5th Plenary Session of The Contact Group on Piracy Off the Coast of Somalia, New York.

CGPCS, 2010c. 6th Meeting of Working Group 2 on Legal Issues, Copenhagen.

CGPCS, 2009a. 1st Meeting of Working Group 2 on Legal Issues, Vienna.

CGPCS, 2009b. 2nd Meeting of Working Group 2 on Legal Issues, Copenhagen.

CGPCS, 2009c. 1st Plenary Session of The Contact Group on Piracy Off the Coast of Somalia, New York.

CGPCS, 2009d. 2nd Plenary Session of The Contact Group on Piracy Off the Coast of Somalia, Cairo.

CGPCS, 2009e. 3rd Plenary Session of The Contact Group on Piracy Off the Coast of Somalia, New York.

CGPCS, 2009f. 4th Plenary Session of The Contact Group on Piracy Off the Coast of Somalia, New York.

CGPCS, 2009g. 4th Meeting of Working Group 2 on Legal Issues, Copenhagen.

Chalk, P., 2008. The Maritime Dimension of International Security: Terrorism, Piracy, and Challenges for the United States. RAND, Santa Monica, California.

Cooper, Andrew F. and Timothy M. Shaw (eds), 2009. The Diplomacies of Small States. Houndmills: Palgrave.

CMF, 2009. New Counter-Piracy Task Force Established [WWW Document]. US Nav. Forces Cent. Command US Fifth Fleet Comb. Marit. Forces. URL http://www.cusnc.navy.mil/articles/2009/001.html

CNN, 2007. U.S. warship can't stop pirates off Somalia [WWW Document]. URL http://edition.cnn.com/2007/WORLD/africa/06/06/pirates/ (accessed 5.27.15).

Coffey, 2014. Annex E: Detailed findings, Evaluation of the Danish Peace and Stabilisation Fund. Danish Ministry of Foreign Affairs.

DANIDA, 2010. Danmarks Deltagelse i Det Internationale Udviklingssamarbejde 2010. Danish Ministry of Foreign Affairs, København. 
Danish Defence, 2015. Overview of Danish participation in military operations in Gulf of Aden [WWW Document]. Pirat. Adenbugten. URL http://www2.forsvaret.dk/videnom/udland/adenbugten/Pages/Adenbugten3.aspx (accessed 5.27.15).

Danish Defence Command, 2008a. THETIS i FN World Food Programme - Efterskrift - Rejsebrev 50 A [WWW Document]. URL http://forsvaret.dk/MST/Enheder/THET/thet08/Pages/200805-05thet50a.aspx

Danish Defence Command, 2008b. Hvorfor fortsætter piratangrebene? [WWW Document]. URL http://forsvaret.dk/MST/Nyt\%20og\%20Presse/internationalt/Pages/Hvorforforts\%C3\%A6tte rpiratangrebene.aspx (accessed 9.30.15).

Danish Defence Command, 2008c. ABSALON har først på eftermiddagen opbragt to formodede piratfartøjer i Aden Bugten [WWW Document]. URL http://forsvaret.dk/MST/Nyt\%20og\%20Presse/pirateri/Pages/2008-09-17pirater.aspx (accessed 12.28.14).

Danish Defence Command, 2008d. Besætningen på ABSALON skiftet - operationen fortsætter [WWW

Document].

URL http://forsvaret.dk/MST/Nyt\%20og\%20Presse/pirateri/Pages/Bes\%C3\%A6tningenp\%C3\% A5ABSALONskiftet\%E2\%80\%93operationenforts\%C3\%A6tter.aspx (accessed 9.1.15).

Danish Minister of Foreign Affairs (Holger K. Nielsen), 2014. Sikkerhedspolitisk redegørelse 2013 af 14/1 14 (Redegørelse nr. R7).

Danish Minister of Foreign Affairs (Lene Espersen), 2010. Regeringens sikkerhedspolitiske redegørelse 2010 af 12/5 2010 (Redegørelse nr. R14).

Danish Ministry of Defence, 2009. Forsvarsforlig 2010-2014, København.

Danish Ministry of Foreign Affairs, 2015. Strategi for den danske indsats mod pirateri 2015-2018. Danish Ministry of Foreign Affairs, Copenhagen.

Danish Ministry of Foreign Affairs, 2011. Strategi for den danske indsats mod pirateri 2011-2014. Danish Ministry of Foreign Affairs, Copenhagen.

Danish Ministry of Foreign Affairs, 2009. Politikpapir for Danmarks engagement i Somalia 2009.

Danish Parliament (Folketinget), 2011. Aktstykke nr. 21, Folketinget 2011-12, Afgjort den 8. december 2011.

Danish Parliament (Folketinget), 2008. B32 (som fremsat): Forslag til folketingsbeslutning om dansk sømilitært bidrag til ledsagelse af skibe med nødhjælp til Somalia chartret af FN's Verdensfødevareprogram.

Grøn, Caroline and Anders Wivel, 2011. 'Maximizing Influence in the European Union after the Lisbon Treaty: From Small State Policy to Smart State Strategy'. Journal of European Integration, 33 (5), 523-39. 
Guilfoyle, D., 2010. Counter-Piracy Law Enforcement and Human Rights. Int. Comp. Law Q. 59, 141.

Fox, Annette Baker, 1959. The Power of Small States. Chicago: Chicago University Press.

Handel, Michael, 1981. Weak Slates in the International System. London: Frank Cass.

House Armed Services Committee, 2009. Statement of Vice Admiral William E. Gortney, U.S. Navy Commander, U.S. Naval Forces Central Command Before The House Armed Services Committee On Counter-Piracy Operations In The U.S. Central Command Area Of Operations.

ICG, 2008. Somalia: To Move Beyond the Failed State (No. 147), Africa Report. International Crisis Group.

IMO Maritime Safety Division, 2014. Djibouti Code of Conduct Newsletter, Edition 4: November 2014-August 2015.

Interview with Alan Cole, 2015. Counter-Piracy Programme and later Transnational Organised Crime Coordinator, Nairobi Office, UN Office on Drugs and Crime (2009-)

Interview with Birgit Feldtmann, 2014. Associate Professor, Department of Law, University of Southern Denmark (2007-); Legal advisor, Working Group 2, Contact Group on Piracy off the Coast of Somalia (2013-).

Interview with Douglas Guilfoyle, 2014. Reader, Faculty of Law, University College London (2007-2015); Legal advisor, Working Group 2, Contact Group on Piracy off the Coast of Somalia (2009-).

Interview with Frank Trojahn, 2015. Commander, HDMS Absalon, Royal Danish Navy (20072008); Chief of Naval Staff, Danish Naval Command, Danish Armed Forces (2013-).

Interview with Michiel Hijmans, 2014. Commander, HMNLS De Ruyter, Royal Netherlands Navy (2010-2011) Commander, Standing Maritime Group 2, NATO (2010-2011).

Interview with Per Bigum Christensen, 2014. Commander, Royal Danish Navy; Commander, Task Force 150, Combined Maritime Forces (2008-2009).

Interview with Thomas Winkler, 2014. Undersecretary, Office for Legal Affairs, Danish Ministry of Foreign Affairs (2008-2013); Chairman, Working Group 2, Contact Group on Piracy off the Coast of Somalia (2009-2013)

Jakobsen, Peter Viggo, 2009. 'Small States, Big Influence: The Overlooked Nordic Influence on the Civilian ESDP'. Journal of Common Market Studies 47 (1), 81-102. 
Jervis, Robert, 1978. 'Cooperation under the Security Dilemma'. World Politics, 30 (2), January, 167-214.

Keohane, Robert O., 1969. 'Lilliputians' Dilemma: Small States in International Politics'. International Organization, 23 (2), 291-310.

Kilcullen, David, 2006. 'Counter-Insurgency Redux'. Survival 48 (4), 111-30.

Krasner, Stephen D. and Carlos Pascual, 2005. 'Addressing State Failure', Foreign Affairs, 84, 153.

Jyllands-Posten, 2008. Piraterne ingen ville røre. Morgenavisen Jyll.-Posten.

Luft, Gal and Anne Korin, 2004. 'Terrorism Goes to Sea'. Foreign Affairs, 83 (6), December, p. 70.

Murphy, M.N., 2007. Contemporary piracy and maritime terrorism: the threat to international security. International Institute for Strategic Studies, London.

Morgenthau, Hans, 1972. Science: Servant or Master? New York: New American Library.

Neumann, Iver B. and Sieglinde Gstöhl, 2006. 'Introduction: Lilliputians in Gulliver's World?' in Christine Ingebritsen, Iver B. Neumann, Sieglinde Gstöhl and Jessica Beyer (eds), Small States in International Relations. Seattle: University of Washington Press, 3-36.

Olson, Mancur and Richard Zeckhauser, 1966. 'An economic theory of alliances'. The Review of Economics and Statistics, 48 (3), 266-79.

Panke, Diana, 2011. 'Small states in EU negotiations: Political dwarfs or power-brokers?'. Cooperation and Conflict, 46 (2), 123-43.

Politiken, 2008. Dansk fregat må slippe piratskib, mens Nato er rådvild over truslen. Politiken.

Riddervold, Marianne, 2014. 'New threats - different response: EU and NATO and Somali piracy', European Security 23(4), 546-564.

Risse, Thomas, 2000. 'Let's argue!': communicative action in world politics'. International Organization, 54(1), 1-39.

Rotberg, Robert I., 2003. 'State Failure and State Weakness in a Time of Terror'. Medford: World Peace Foundation, 1-25.

Rothstein, Robert, 1968. Alliances and Small Powers. New York: Columbia University Press. 
Smed, U.T., 2015a. Navigating Narrow Seas - Strategic Culture and Small State Influence Seeking on the International Counterpiracy Agenda. Department of Political Science, University of Copenhagen, Copenhagen, Denmark.

Smed, U.T., 2015b. Small states in the CGPCS: Denmark, Working Group 2, and the end of the debate on an international piracy court. Presented at the Contact Group on Piracy off the Coast of Somalia, Lessons Learned Project.

Struwe, L.B., 2009. For a Greater Horn of Africa Sea Patrol. Danish Institute for Military Studies, Copenhagen.

The Guardian, 2013. No Somali pirate hijacking in nearly a year, says UN [WWW Document]. URL http://www.theguardian.com/world/2013/may/03/somali-pirate-hijacking (accessed 1.20.16).

Thompson, Alexander, 2015. Channels of power: The UN Security Council and US statecraft in Iraq. Ithaca: Cornell University Press.

Thorhallsson, Baldur, 2006. 'The Size of Sates in the European Union: Theoretical and Conceptual Perspectives'. Journal of European Integration, 28 (1), 7-31

UNODC, 2015. Maritime Crime Programme - Annual Report 2014. Regional Office for Eastern Africa, Nairobi, Kenya.

UNODC, 2012. Counter Piracy Programme Brochure 2012 (No. Issue 10). Regional Office for Eastern Africa, Nairobi, Kenya.

UNSC, 2013. Resolution 2125 (2013).

UNSC, 2012a. Report of the Secretary-General on specialized anti-piracy courts in Somalia and other States in the region.

UNSC, 2012b. Resolution 2077 (2012).

UNSC, 2011a. S/2011/30: Letter dated 24 January 2011 from the Secretary-General to the President of the Security Council.

UNSC, 2011b. Report of the Secretary-General on the modalities for the establishment of specialized Somali anti-piracy courts.

UNSC, 2011c. Report of the Secretary-General pursuant to Security Council resolution 1950 (2010).

UNSC, 2011d. Resolution 1976 (2011).

UNSC, 2011e. S/2011/360: Report of the Secretary-General on the modalities for the establishment of specialized Somali anti-piracy courts.

UNSC, 2011f. Resolution 2015 (2011). 
UNSC, 2011g. Resolution 2020 (2011).

UNSC, 2010a. Report of the Secretary-General pursuant to Security Council resolution 1897 (2009).

UNSC, 2010b. Resolution 1918 (2010).

UNSC, 2008a. Resolution 1838 (2008).

UNSC, 2008b. Resolution 1801 (2008).

UNSC, 2007. Resolution 1772 (2007).

UNSG, 2007. S/2007/566: Letter dated 20 September 2007 from the Secretary-General addressed to the President of the Security Council.

Väyrynen, Raimo, 1971. 'On the definition and measurement of small power status', Cooperation and Conflict, 6 (1), p. 91-102.

Vital, David, 1967. The Inequality of States: A Study of the Small Power in International Relations. Oxford: Clarendon Press.

Weekendavisen, 2008a. Pirateri: Pirater og deres menneskerettigheder. Weekendavisen.

Weekendavisen, 2008b. Piratjagt: Syv mænd med bare tæer. Weekendavisen.

Westberg, Andreas Bruvik, 2015. 'Bloodshed and Breaking Wave: The First Outbreak of Somali Piracy’. Scientia Militaria: South African Journal of Military Studies, 43 (2), 1-38. 